\title{
Styring i spændingsfeltet mellem vilde problemer og stramme budgetter ${ }^{1}$
}

\author{
Af Per Nikolaj Bukh og Anne Kirstine Svanholt*)
}

\section{Resumé}

Dynamikkerne, kompleksiteten og de vilde problemer på socialområdet har ofte indebåret, at socialt arbejde har været opfattet som svært styrbart ud fra et økonomisk perspektiv. I denne artikel analyseres det, hvordan en kommune efter finanskrisen reorganiserede økonomistyringen for at sikre en mere stram budgetstyring samtidig med at de decentrale frihedsgrader blev bevaret. Vi anvender Levers of Control-begrebsapparatet til at vise, hvordan traditionelle budgetog planlægningsprocesser og -systemer anvendes fleksibelt og dynamisk som såkaldte interaktive styringssystemer. Analysen indikerer, at interaktiv brug af budgetstyring kan fremme fleksibilitet i den offentlige sektor og skabe rum for innovation og læring, således at den faglige dømmekraft styrkes, samtidig med at den økonomiske forudsigelighed og budgetoverholdelsen forbedres.

*) Per Nikolaj Bukh er cand. oecon og ph.d. samt professor i økonomistyring ved Aalborg Universitet. Anne Kirstine Svanholt er cand. soc. i udviklingsstudier fra Aalborg Universitet og enhedsleder i socialforvaltningen i Københavns Kommune. 


\section{A. Indledning}

\section{Artiklens baggrund}

Den finansielle og økonomiske krise, der ramte Danmark i 2008, markerede på mange punkter et vendepunkt i den kommunale økonomistyring, hvor den administrative mål- og resultatstyring i de fleste kommuner blev suppleret, eller måske ligefrem ned tonet (Sørensen \& Foged 2015) til fordel for en stram økonomisk styring med fokus på budgetoverholdelse (Foged et al. 2017). Andre lande blev hårdere ramt af krisen og var nødsaget til både at reducere de offentlige udgifter og øge skatterne for at bringe den offentlige økonomi i bedre balance og reducere den offentlige gældsætning. Krisen førte derfor også internationalt til et øget fokus på en stram budgetstyring med henblik på at reducere omkostninger og forøge effekten (Knutsson et al. 2008; Pollitt \& Bouckaert 2017; Kolk et al. 2015) I forlængelse heraf kom såkaldte austerity-politikker (jf. Bracci et al. 2015; Pollitt \& Bouckaert, 2017) og fiscal squeeze (Hood \& Heald 2014) i fokus.

Selvom Danmark var i langt bedre økonomisk form end de fleste andre europæiske lande, fik den politiske dagsorden fokus på at sænke skatterne og øge produktivitet i den private sektor for at skabe vækst. Derfor nedsatte regeringen i foråret 2012 en produktivitetskommission, der i sin afrapportering (Produktivitetskommissionens 2014) anbefalede, at der på alle områder i den offentlige sektor blev formuleret klare politiske krav om høj produktivitet og effektivitet, samtidig med at ledere og medarbejdere burde have flere frihedsgrader i opgaveløsningen. Det blev også anbefalet, at lederne, via økonomistyringen, fik mere fokus på kerneopgaven og den overordnede strategi, samt at principperne for ramme- og takststyring på en række områder blev justeret.

Det var en udvikling, der allerede var i gang på de kommunale serviceområder herhjemme, og som også kunne genfindes i studier af kommunal økonomistyring i flere andre lande, hvor der var behov for både budgetoverholdelse og forøget kvalitet på velfærdsområderne (Ahrens \& Ferry 2015; Johansson \& Siverbo 2014; Kolk et al. 2015). Det forøgede fokus på stram budgetstyring (Van der Stede 2001), forøger dog kompleksiteten, ikke mindst på socialområdet, hvor mange af de sociale problemstillinger opfattes som uklart definerede, sammenhængende på tværs af sektorområder samt afhængige af politiske vurderinger frem for videnskabeligt funderet evidens (Head 2008). 


\section{2. Økonomistyring af vilde problemer}

Udfordringerne på socialområdet betegnes ofte "vilde problemer" (Devaney \& Spratt 2009; Krogstrup 1997, 2011) med henvisning til Rittel \& Webber's (1973, p. 160) karakteristik. Betegnelsen vilde problemer blev anvendt for at markere en afstandtagen til de rationelle og tekniske tilgange, der ofte stillede umulige mål- og resultatkrav ved løsningen af de offentlige opgaver. Rittel \& Weber (1973) fandt, at vilde problemer i højere grad indebar politiske og skønsmæssige vurderinger fremfor evidensbaseret viden samtidig med, at en rent rationel tilgang ofte førte til, at borgernes egne oplevede erfaringer og involverede aktørers perspektiver blev negligeret. I modsætning til "tamme problemer" blev vilde problemer opfattet som resistente mod en entydig problemafklaring og en klar og alment accepteret løsning samtidig med, at interventioner på området i høj grad blev set som skønsbaserede. I litteraturen beskrives de tamme problemer i modsætning til vilde problemer ved at kausalitet kan fastslås mellem problem og løsning, f.eks. ved hjælp af velkendte standarder, metoder og evidens (Head 2008). I forhold til vilde problemer er den manglende klare viden om, hvad der bør gøres, ikke kun en styringsmæssig udfordring, men i høj grad en faglige udfordring, da det er afgørende at træffe de bedst mulige beslutninger, fordi de valg, der træffes på socialområdet, har vidtrækkende konsekvenser, og kun vanskeligt kan omgøres, som også Bracci \& Llewellyn (2012) pointerer. Det er en del af karakteristikken, at det er udfordrende at håndtere vilde problemer, fordi det svært at forudsige, hvilke konsekvenser interventioner vil have, og hvad der egentlig er årsagen til det, der opnås (Head 2008). Blackman et al. (2006) fremhæver de komplekse interaktioner, hvor resultaterne afhænger af den specifikke kontekst og først manifesterer sig flere år efter indsatsen. Derfor er det kompliceret at styre efter klare og målbare resultater.

Den høje grad af kompleksitet på socialområdet indebærer usikkerhed på grund af den manglende viden om problemernes natur og om løsningernes effektivitet (Llewellyn 1998), og fordi de involverede aktører ofte ikke har den samme opfattelse af, hvilke problemstillinger der er involverede, og hvilke løsninger, der er mulige (van Bueren et al. 2003), eller i det hele taget samme opfattelser af, hvad der karakteriserer gode præstationer i den offentlige sektor (Amirkhanyan et al. 2014; Pollitt 2006; van Thiel \& Leeuw 2002).

Jacobs \& Cuganesan (2014) påpeger, at mange af udfordringerne, når vilde problemer skal adresseres, involverer økonomistyring. Dette er ikke kun et spørgsmål om at vide, hvilke interventioner der virker, men også et spørgsmål om “[h]ow to account for outcomes that emerge 
in the long term and as the indivisible result of the effort of many contributors" (Jacobs \& Cuganesan 2014, p. 1252). Det økonomiske pres på socialområdet efter finanskrisen har fået de fleste kommuner til at fokusere på en strammere økonomisk styring og forøge kravene om budgetoverholdelse tilsvarende, hvad der har været set i mange andre lande (Johansen \& Siverbo 2014).

Imidlertid kan et overdrevet fokus på kortsigtede mål og budgetoverholdelse i et længere perspektiv vise sig ineffektivt (Klok et al. 2015). Det er derfor afgørende, hvordan økonomistyringen designes, ikke mindst, fordi vilde problemer, som anført af Head \& Alford (2015), ofte indebærer løsninger, der ikke kan standardiseres og en høj grad af fleksibilitet, da de enkelte problemstillinger kan fremstå unikke, og fordi der løbende skal ageres under høj usikkerhed.

Simons (1995) har på baggrund af en række studier af store nordamerikanske virksomheders integrerede styringspraksis udviklet det såkaldte Levers of Control (LOC) begrebsapparat for at forstå, hvordan modsatrettede dynamikker mellem "freedom and constraint, between empowerment and accountability, between top-down direction and bottom-up creativity, between experimentation and efficiency" (Simons, 1995, p. 4) kan håndteres ved simultan anvendelse af flere styringsprincipper og -teknikker.

Blandt de fire styringssystemer, betegnet løftestænger ('levers'), som Simons identificerede, har de to en begrænsende ('constraining') rolle og de andre to en muliggørende ('enabling') rolle (Tessier \& Otley 2012). De muliggørende styringssystemer udgøres af værdisystemer ('belief systems') og interaktive styringssystemer ('interactive control systems'), mens de begrænsende styringssystemer omfatter grænsesystemer ('boundary systems') og diagnostiske styringssystemer ('diagnostic control systems').

Der argumenteres ofte for, hvordan styring begrænser adfærd og reducerer kreativitet (Gilson et al. 2015; Hirst et al. 2001). Studier (f.eks. Speklé et al. 2017), der anvender LOC-begrebsrammen, har imidlertid dokumenteret, at der ikke behøver at være modstrid mellem styring og kreativitet, og at styring omfatter en mængde mekanismer, hvoriblandt nogle som fremhævet af Speklé et al. (2017,) fremmer de resultater, der ønskes opnået (f.eks. Grabner 2014; Marginson et al. 2014). 
Det er især den interaktive brug af styringssystemer, der har fået opmærksomhed i litteraturen (Martyn et al. 2016). Flere studier af integreret styring i den offentlige sektor (f.eks. Kominis \& Dudau; Kloot 1997; Batac \& Carassus 2009; Kober et al. 2007; Di Francesco \& Alford 2016; Kastberg \& Siverbo 2016) har således vist, hvordan traditionelle budget- og planlægningssystemer komplementeres af interaktive styringsprincipper for både at opnå en økonomisk styrbarhed og samtidig sikre kreativitet, innovation og organisatorisk læring under hensyntagen til usikkerhed.

\section{Formål og oversigt over artiklen}

Hvad angår litteraturen om vilde problemer (Head \& Alford 2015; Blackman et al. 2006; Durant \& Legge 2006) er der oftest mindre fokus på økonomistyring, og det adresseres i særdeleshed ikke, om interaktive styringsprincipper kan medvirke til at løse vilde problemer, samtidig med at de økonomiske styringsmålsætninger realiseres. Økonomistyringslitteraturen (f.eks. Kominis \& Dudau 2012; Kloot 1997; Kober 2007) erkender velfærdsområdernes styringsmæssige kompleksitet, men har ikke fokus på, hvilken rolle økonomistyring spiller ved adresseringen af vilde problemer, når budgetoverholdelse samtidig skal sikres. Denne artikel har som formål at adressere dette, og forskningsspørgsmålet er derfor: Hvordan kan økonomistyringssystemer simultant understøtte adresseringen af vilde problemer og styrbar budgetoverholdelse på det specialiserede socialområde.

Den empiriske del af artiklen er baseret på et kvalitativt studie i en dansk kommune, der er anonymiseret, og som vi i artiklen betegner Beta. Kommunen har en gennemsnitlig størrelse og var omkring 2010 ligesom så mange andre kommuner økonomisk presset af stigende udgifter på de specialiserede socialområder. Vi valgte at studere den økonomiske styring i netop denne kommune, da den ved en uformel rundspørge blandt mange med erfaring fra området blev udpeget som en kommune, der havde en velfungerende dialogbaseret aftalestyring, og som havde formået at kombinere decentrale frihedsgrader med en stram økonomisk styring.

Økonomistyring bliver ofte opfattet som begrænsende for det faglige virkefelt, og meget litteratur (f.eks. Bruijn 2007; Dooren et al. 2015) har påpeget, at dårlig styring, ofte associeret med New Public Management (Hood 1989, 1991), har en række uhensigtsmæssige konsekvenser og bliver en forhindring for at opnå faglige resultater. Der er imidlertid også behov for at studere 
økonomisk styring, der fungerer og skaber bedre organisationer, der fungerer mere omkostningseffektivt - og både formår at skabe faglige resultater og holde budgetter. Derfor responderer vi med denne artikel på Jakobs \& Cuganesan (2014) såvel som Cuganesan et al. (2014), der argumenterer for, at forskningen også skal studere, hvordan økonomistyringssystemer og praksisser i offentlige virksomheder kan designes og implementeres, så der skabes positive konsekvenser, der kan overstige de ulemper og risici, der kan være forbundet med øget styring. Ved at skabe indsigt i økonomistyring i praksis er det også vores forhåbning, at praksisrelevansen af forskningen styrkes, hvilket ofte (Aguinis \& Pierce 2008; Berry et al. 2009; Hall 2010; Van der Stede 2015) har været efterspurgt i litteraturen.

Specifikt bidrager artiklen med at vise, hvordan styringsprocesser kan fremme kreativitet i den offentlige sektor og skabe rum for innovation og læring samt styrke den fagprofessionelle dømmekraft samtidig med, at styringen kan bidrage til at opnå en styrbarhed i forhold til budgetoverholdelse. Artiklen bidrager dermed til den voksende litteratur om økonomistyring i den offentlige sektor (Kloot 1997, Batac \& Carassus 2009, Kober et al. 2007, Abernethy \& Brown 1999, Kominis \& Dudau 2012) ved at vise, hvordan en kommune på det specialiserede socialområde i praksis har designet styringssystemer, der komplementerer hinanden. En begrænset mængde litteratur (f.eks. Kominis \& Dudau 2012, Østergren 2009, Nyland \& Pettersen 2004, Pettersen \& Solstad 2015) har fokus på anvendelsen af systemerne, fremfor deres tekniske egenskaber, og vi bidrager i særdeleshed til denne litteratur.

Den resterende del af artiklen er struktureret således, at afsnit B giver et kort oprids af de kommunale styringsvilkår og den specialiserede socialsektor. Dernæst introducerer afsnit C den analytiske begrebsramme, Levers of Control, og afsnit D beskriver metodologien. Vi præsenterer de empiriske resultater i afsnit $\mathrm{E}$, diskuterer disse i forhold til teorien i afsnit $\mathrm{F}$, hvorefter vi konkluderer i afsnit G.

\section{B. Analytisk begrebsramme}

Det er et udbredt argument i litteraturen (f.eks. Otley 1999; Ferreira \& Otley 2009; Broadbent \& Laughlin 2009; Malmi \& Brown 2008), at økonomistyringens funktionalitet og konsekvenser skal analyseres som en samlet styringspakke (Bedford et al. 2016; Kolk 2019; Malmi \& Brown 2008) fremfor at studere de tekniske egenskaber ved enkelte teknikker eller systemer. Dette gælder ikke 
mindst, når det skal vurderes, hvordan økonomistyring påvirker, om organisationer lykkes med innovation og organisatorisk læring (Bedford 2015; Mundy 2010).

Vi anvender i denne artikel Simons' (1995) Levers of Control (LOC) begrebsramme til at analysere, hvordan traditionelle økonomistyringsteknikker, som f.eks. budgetlægning kombineres med andre styringselementer. LOC fokuserer eksplicit på samspillet mellem formelle styringssystemer frem for deres tekniske egenskaber og de formål, som det er udviklet til. Denne begrebsramme har i flere tidligere studier (f.eks. Kruis et al. 2016; Speklé et al. 2017; Cuganesan \& Donovan 2011) været anvendt til at analysere, hvordan forskellige styringssystemer er kombineret, og hvordan de spiller sammen med adresseringen af vilde problemer.

\section{Levers-of-Control}

Simons (1995) identificerede fire typer styringssystemer, hvoraf to af dem (værdisystemer og interaktive styringssystemer) defineres som positive og to af dem (grænsesystemer og diagnostiske styringssystemer) defineres som negative. Vi følger Tessier \& Otley (2012), der argumenterer for at anvende termerne "muliggørende" og "begrænsende" styringssystemer for at undgå forveksling med kvaliteten af styringen, dvs. om den fungerer godt eller skidt. Ved at anvende styringssystemer i en dual rolle skabes et dynamisk spændingsfelt, så de strategiske målsætninger kan realisere afsøgning af muligheder og løsning af problemer (Mundy 2010, p 499).

Den første type styringssystem er vardisystemerne, der fremmer afsøgningen efter nye og attraktive muligheder ved at kommunikere værdier, formål og retning, samt ved at inspirere ledere og medarbejdere til at tilslutte sig til de organisatoriske målsætninger. Dermed er værdisystemerne mulighedsskabende systemer, der signalerer de mål og værdier, der ikke er eksplicitte i de organisatoriske rutiner og processer (Frow et al. 2010; Mundy 2010).

Grænsesystemer er begrænsende systemer, som ifølge Simons (1995) angiver grænser og begrænsninger, når muligheder afsøges. Dermed reduceres strategiske risici ved at etablere spilleregler for, hvad der er acceptabelt, samt ved at identificere handlinger og udfordringer, der skal undgås, så der ikke spildes ressourcer. Der kan f.eks. være tale om styringssystemer, der angiver minimumsstandarder eller adfærdskodekser og grænsesystemerne kan både være baseret 
på finansielle og non-finansielle data (Frow et al. 2010). Ligeledes kan der være tale om retningslinjer, der regulerer den fagprofessionelle kompetence.

Diagnostiske styringssystemer koordinerer og monitorerer implementeringen af strategien og har som formål at identificere undtagelser og afvigelser fra planen (Simons 1995, p. 59). Dermed repræsenterer diagnostiske styringssystemer den traditionelle brug af MCS, hvor der foretages korrigerende handlinger på baggrund af feedback om resultaterne (Mundy 2010; Marginson \& Ogden 2005; Bedford 2015). Diagnostiske styringssystemer fordrer ideelt set, at mål er klare og utvetydige, og at det er muligt at måle resultater, der er konsistente med, hvad der ønskes opnået (Speklé \& Verbeeten 2014). Det er derfor, de traditionelle diagnostiske styringssystemer er udfordrede, når vilde problemer skal håndteres, da det er vanskeligt at definere målsætninger og måle resultater (Blackman et al. 2006).

De interaktive styringssystemer er i deres tekniske natur identiske med de diagnostiske i den forstand, at de også er feedback og målingssystemer (Martyn et al. 2016), men forskellen er relateret til brugen af informationen frem for det tekniske systemdesign (Naranjo-Gill 2016). Simon (2000, p. 216) definerer selv interaktive styringssystemer, som informationssystemer "that managers use to personally involve themselves in the decision activities of subordinates". Interaktive styringssystemer er muliggørende, idet de stimulerer og guider udviklingen af nye strategier, sikrer ledelsens fokus på de strategiske usikkerheder og fremmer læring om, hvordan der kan responderes på trusler og muligheder (Janke et al. 2014).

Simons (1995) lægger vægt på, at mange typer af styringssystemer, og i særdeleshed ikke kun økonomiske styring, kan blive anvendt interaktivt. Det kan f.eks. være faste møderækker, hvor analyser og information benyttes til at identificere og respondere på udfordringer. Det er altså brugen af systemet, der er væsentlig ved de interaktive styringssystemer, og den interaktive styring sker ved, at ledelsen gennem personligt engagement kontinuerligt udfordrer ledere længere nede i hierarkiet til at identificere og forklare forandringer på deres område og redegøre for forslåede handleplaner og de analyser, som de ligger til grund.

\section{Erfaringer med anvendelsen af begrebsrammen}

Simons (1990, 1991, 1995) udviklede LOC på baggrund af feltstudier i private virksomheder, men begrebsrammen har i adskillige studier været anvendt i studier af offentlige virksomheder. Blandt 
45 studier udgivet i akademiske toptidsskrifter inden for regnskabsvæsen, økonomistyring samt strategisk og generel ledelse, identificerede Martyn et al. (2016) således 11 studier inden for den offentlige sektor samt yderligere ét foretaget i en NGO.

Studier inden for den offentlige sektor har især fokuseret på, hvordan interaktive styringssystemer sikrer organisatorisk læring, innovation og strategisk udvikling (f.eks. Kloot 1997; Kober 2007; Naranjo-Gil 2016). Interaktive styringssystemer skaber øget opmærksomhed omkring økonomistyringen (Tuomela 2005), hvilket kan øge modstanden i organisationen, hvis de styringsmæssige målsætninger kommer i konflikt med medarbejdernes værdier og holdninger. Men som også Deschamps (2019) pointerer, kan den offentlige sektors kompleksitet netop indebære, at en interaktiv brug af økonomistyring kan øge succesen for, at styringsreformer lykkes ved at skabe et stærkt ledelsesrum (Guenther \& Heinicke 2019; Kominis \& Dudau 2012; Moynihan \& Kroll 2016).

Når adresseringen af vilde problemer skal analyseres, er samspillet mellem styringssystemerne, frem for deres tekniske egenskaber, afgørende på grund af den iboende kompleksitet og de modsatrettede dynamikker. De mål, der anvendes i traditionelle diagnostiske styringssystemer til at måle resultatopnåelsen i forhold til målsætninger og budgetter, kan som anført af Kominis \& Dudau (2012) også anvendes interaktivt til at identificere nye udfordringer og reducere risici og usikkerhed, eller som Widener (2007) viser, kan de anvendes til at strukturere og fremme diskussioner, der gør organisationen i stand til at skabe nye løsninger. Omvendt kan en manglende balancering mellem styringssystemerne resultere i nedsat beslutningskraft, spild af ressourcer, ustabilitet og dårligere resultatopnåelse. Eksempelvis argumenterer Henri (2006) for, at en uhensigtsmæssig brug af diagnostiske styringssystemer kan få organisationen til at fokusere forkert, ligesom en overdreven diagnostisk styring kan hæmme innovation og kreativitet. Hertil kommer, at en uhensigtsmæssig brug af grænsesystemer kan skabe rigide organisationer, der forhindrer medarbejderne i at afsøge alternative og potentielt mere egnede løsninger.

LOC-begrebsrammen fokuserer på at håndtere dynamikkerne mellem kreativ innovation og forudsigelig målopnåelse, og det er i særdeleshed kritisk, hvordan de mulighedsskabende styringssystemer anvendes (Bisbe \& Otley, 2004; Tuomela 2005). De diagnostiske styringssystemer begrænser fleksibilitet og innovation, mens de interaktive har den modsatte effekt. I litteraturen om vilde problemer har det været demonstreret, at traditionelle 
styringssystemer kan være nødvendige, men også at de kan være utilstrækkelige, hvis ikke de suppleres med styring, der fremmer fleksibilitet og kreativitet (Blackman et al. 2006; Durant \& Legge Jr. 2006; Head \& Alford 2015). Tilsvarende har litteraturen, der anvender LOC i relation til den offentlige sektor vist, at interaktive styringssystemer har en afgørende rolle for organisatorisk læring (Kloot 1997; Carassus 2009; Abernethy \& Brownell 1999) og håndtering af usikkerhed (Kominis \& Dudau 2012).

Specielt usikkerhed har en markant rolle i LOC begrebsrammen. I henhold til Chenhall (2007) kan usikkerhed opfattes som situationer, hvor der ikke med tilstrækkelig sikkerhed kan angives sandsynligheder for, at årsags-effekt relationer holder, eller hvor ændringer i omgivelserne er uforudsigelige. Van Bueren (2003) argumenterer for, at usikkerheden er høj, når der er vilde problemer involveret, fordi det netop er svært at definere problemer og løsninger, når der mangles viden, og fordi der er divergerende holdninger og værdisæt hos aktørerne involveret.

\section{Det specialiserede socialområde og organiseringen i Beta}

Den empiriske del af artiklen er baseret på et casestudie af styringen på det specialisede voksenområde i en mellemstor kommune i maj 2012. Kommunen, som vi betegner Beta, blev udvalgt på baggrund af kontakter til centrale aktører på området, samt uformelle forespørgsler om, hvilke kommuner der generelt blev opfattet som veldrevne og succesfulde på socialområdet. Der blev udvalgt 5 kommuner, som grundlag for et ph.d.-projekt. Vi har i anden sammenhæng (Bukh \& Svanholt 2019a, 2019b; Svanholt 2013) analyseret resultaterne fra to af de andre kommuner.

\section{Udfordringerne på socialområdet}

Kommunerne bruger årligt ca. 45 milliarder kroner

${ }^{2}$ på det specialiserede socialområde. Heraf udgør udgifterne til udsatte børn og unge omkring en tredjedel, mens indsatser til udsatte voksne og personer med handicap udgør to tredjedele, svarende til 30 milliarder (KL et al. 2017). Dermed udgør udgifterne til socialområdet mere end $17 \%$ af de kommunale serviceudgifter, hvilket er mere end f.eks. de samlede udgifter på folkeskoleområdet. Frem mod Strukturreformen steg de kommunale udgifter på socialområdet, selvom skiftende regeringer havde haft som målsætning at bremse udgiftsvæksten. I perioden fra 2004 til 2008 steg udgifterne således årligt omkring én milliard kroner (Finansministeriet 2009), 
og den samlede budgetoverskridelse på de kommunale serviceudgifter nåede i 2009-regnskaberne op på over 5 milliarder kroner, hvilket var en historisk rekord.

Da kommunerne efter Strukturreformen overtog det fulde finansielle ansvar for socialområdet, var det den politiske forventning, at det gav klare incitamenter til at holde omkostningerne så lave som muligt (Pedersen 2008). Imidlertid fortsatte udgifterne med at vokse, og fra 2007 til 2010 var de steget med omkring 10\%. Analyser (Finansministeriet 2009) indikerede, at kommunerne ofte havde utilstrækkeligt fokus på økonomistyringen, blandt andet fordi det specialiserede socialområde blev opfattet som svært styrbart (Houlberg 1999), ligesom den statslige styring af kommunernes udgifter udelukkende var baseret på økonomiaftalerne, som var frivillige og kollektive, og som fastlagde en årlig økonomisk ramme, som kommunerne under ét skulle overholde (Blom-Hansen et al. 2012; Houlberg 2017).

\section{Fokus på stram udgiftsstyring og budgetoverholdelse}

I aftalen om kommunernes økonomi for 2009 var der imidlertid enighed mellem regeringen og KL om at igangsætte et arbejde med henblik på at udvikle redskaber, der fremadrettet kunne understøtte kommunernes indsats og prioritering af det specialiserede socialområde. I forlængelse af økonomiaftalen udgav KL, Indenrigs- og Socialministeriet samt Finansministeriet desuden i fællesskab en pjece, hvor det blev slået fast, at

Serviceloven er en rammelovgivning, der giver fleksibilitet for den enkelte kommunalbestyrelse i forhold til sammensætningen af løsninger og anvendelsen af faglige metoder. Kommunalbestyrelserne har således styringsmuligheder i forhold til at tilrettelægge tilbuddene med forskelligt indhold. Kommunalbestyrelsen kan inden for rammerne af lovgivningen og de forvaltningsretlige grundsætninger vedtage, hvilket serviceniveau der ønskes i kommunen.

(Finansministeriet et al., 2009)

Med økonomiaftalen for 2010 og sanktionslovgivningens indførelse i 2011 blev statens styring af kommunerne forøget, da de "frivillige" aftaler blev erstattet med reelle økonomiske sanktionsmuligheder (Foged 2015; Madsen \& Wisén 2019). Der blev på det kommunale område indført et såkaldt betinget bloktilskud på 3 milliarder kroner, som ville blive modregnet kollektivt, hvis kommunerne overskred den aftalte ramme i budgetlægningen. Ligeledes ville kommunerne, hvis de havde overskredet rammen, når regnskaberne blev talt sammen, blive modregnet i 
bloktilskuddet: $40 \%$ kollektivt og 60\% for de kommuner, der overskred budgetterne. Understøttet af budgetloven fra 2012 indebar dette styringsregime en særdeles stærk incitamentsstruktur (Suenson et al. 2016), hvor kommunerne var nødt til at holde budgetterne, hvilken fik mange kommuner til at styrke økonomistyringen (Foged et al. 2017), styrke koncernstyringen (Moll 2017) og tage nye principper i brug.

Når vi i dag ser tilbage på udviklingen i udgiftsbehov og kommunale udgifter fra reformen i 2007 til nu, er det overordnede billede, at der i 2018 blev brugt stor set det samme beløb som i 2007, og at stigningen fra 2007 til 2010 allerede året efter var stort set elimineret, idet udgifterne fra 2010 til 2011 faldt med omkring 3 milliarder kroner. Dette dækker over, at der har været en stigning i udgifterne til borgere med lettere problematikker, f.eks. modtagere af socialpædagogisk støtte, mens udgifterne til længevarende botilbud efter serviceloven har været faldende. Denne udvikling skal dog også ses i lyset af, at der i samme periode er sket en omlægning af botilbud efter serviceloven til almenboliglovgivningen, hvilket indebærer en ændret kontering af udgifterne (jf. KL et al. 2017).

\section{Organisering og styring i Beta}

Med omkring 50.000 indbyggere er Beta en mellemstor kommune. I lighed med mange andre kommuner havde Beta i årene efter strukturreformen haft betydelige budgetoverskridelser på socialområdet, men i 2010 lykkedes det at vende udviklingen, så området udviste mindreforbrug. Således var et merforbrug i 2008 på omkring 20 millioner kroner vendt til et mindreforbrug for omkring 10 millioner kroner i 2011 . Omdrejningspunktet for den politiske og administrative styring i Beta er en dialogbaseret aftalestyring, hvor de enkelte decentrale enheder, betegnet aftaleholdere, indgår i en løbende dialog med fagchefer og chefer for stabe. Disse enheder er også aftaleholdere og er placeret på samme organisatoriske niveau som de sociale tilbud.

Vi fokuserer i artiklen på det specialiserede voksenområde, der i altovervejende grad omfatter tilbud, der, i henhold til serviceloven, gives til voksne med fysiske eller psykiske funktionsnedsættelser eller med særlige sociale problemer, som betyder, at de har brug for specialiserede indsatser. Mange af borgerne i disse målgrupper er desuden påvirket af flere problemstillinger, og de vil ofte også modtage tilbud fra andre forvaltninger eller være i kontakt med sundhedsvæsnet. Ligeledes øges kompleksiteten af, at udgifterne til udsatte voksne og personer med handicap også inden for kommunen er svære at afgrænse, fordi kommuner i deres 
kontering af udgifter til ældre og personer med handicap mv. ikke skelner entydigt mellem, om hvad årsagen til funktionsnedsættelsen er.

Udover det politiske niveau i form af kommunalbestyrelse og socialudvalg, er kommunen ledet af en direktion på tre personer og fagchefer, der på traditionel vis refererer til direktører med specifikt fagansvar i forhold til udvalgene. Til forskel fra den traditionelle forvaltningsmodel, der anvendes i de fleste kommuner, refererer de sociale tilbud på udførerområdet i Beta ikke direkte til fagcheferne. Selvom cheferne er overordnet forstanderne, kan de altså formelt set ikke direkte beslutte om driften i tilbuddene.

Det specialiserede voksenområde er i Beta organiseret med udgangspunkt i en klassisk BUMmodel (Hansen 2019; Nørrelykke et al. 2011) med en myndighedsafdeling, der har visitionsansvar, samt en række udførerenheder. Myndighedsafdelingen kan opfattes som et omkostningscenter, der har et fast udgiftsbudget til drift af afdelingen, herunder sagsbehandling og visitation, mv. samt fast visitionsbudget, der anvendes til at købe ydelser fra udførerne, fra andre kommuner og regioner eller private leverandører. Udførerne er ikke underlagt ét samlet budget, men er derimod styringsmæssigt struktureret som separate profitcentre, med indtægter fra salg af ydelser til myndighedsafdelingen såvel som til andre kommuner og et udgiftsbudget til driften af tilbuddet.

\section{Metodologi}

Det empiriske grundlag for artiklen udgøres af semistrukturerede interview samt dokumenter i form af dels interne dokumenter (budgetter, opfølgninger og analyser, dokumenter vedr. politikker og strategier, politiske notater mv.), som vi indsamlede i forbindelse med besøg hos kommunen, og dels dokumenter, der var tilgængelige på kommunens hjemmeside. Interviewdata vil være påvirket af interviewsituationen og den bias, som uforvarende kan opstå, mens dokumenter findes i forvejen, hvorfor de i højere grad repræsenterer, "what participants are actually doing in the world - without being dependent on being asked by researchers" (Silverman 2014, p. 276). Ved at sammenholde disse to datakilder styrkes studiets validitet. Vi oplevede ikke nogen begrænsninger i dataadgangen udover, at der i sagens natur ikke var adgang til information om enkelte borgere. 
Det blev i alt foretaget 7 interview, hvoraf 5 var med ledere på det specialiserede voksenområde og 2 var med henholdsvis budgetchefen i den centrale økonomiafdeling og en økonomikonsulent ansat i den centrale økonomiafdeling. Lederne fra socialafdelingen var socialchefen og lederen af myndighedsafdelingen (myndighedslederen) samt tre medarbejdere, der fungerede som forstandere. Interviewguiden var struktureret i 6 temaer: Det første tema omfattede spørgsmål vedrørende de interviewedes baggrund og erfaring, dernæst drejede andet tema sig om kommunens organisering, historik samt nuværende og kommende udfordringer. Det tredje tema vedrørte bredt elementerne i kommunens styring, det fjerde fokuserede specifikt på budgetprocessen og det femte tema adresserede den langsigtede planlægning. Endelig spurgte vi inden for det sjette tema om samarbejde eksternt og internt samt om kommunikationen og interaktionen mellem det politiske og administrative niveau.

Alle interview varede mellem 1 og 2 timer, og blev optaget samt transskriberet. Herefter blev interview såvel som dokumenter analyseret ved anvendelse af softwarepakken NVIVO 10. Ved at anvende en systematisk fremgangsmåde ved datareduktion, kodning og klassifikation samt fortolkning af data reduceredes den analytiske bias. Vi anvendte NVIVO til at kode data samt afprøve og strukturere relationer mellem teoretiske begreber, data og interviewtemaer. Indledningsvist kodede vi data efter LOC begrebsrammen for at identificere de enkelte styringselementer, hvorefter vi kodede med henblik på at identificere værktøjer, metoder, principper mv. og forbedre forståelse for styringssystemerne. Vi lagde ved analysen især vægt på, hvordan budget- og planlægningsprocesserne var strukturerede.

\section{E. Styringssystemerne i praksis}

\section{Aftalestyring som grundprincip}

Overordnet set er økonomistyringen i Beta baseret på et dialogbaseret aftalesystem, hvor alle forstanderne er defineret som aftaleholdere, og hvor forstanderne er ansvarlige for at lede deres tilbud inden for aftalens rammer: 
Formålet med aftalestyringen er, at politikerne giver den overordnede retning til udviklingen af kommunens service. På baggrund heraf skal aftaleholderne styre og udvikle kommunens service i overensstemmelse med aftalestyringens rammer og principper, så anvendelsen af kommunens ressourcer giver størst mulig værdi for kommunens borgere og brugere.

(Koncept for aftalestyring, 2010)

De mål, der indgår i aftalerne, kaskaderes i en årlig proces fra det politiske til det udførende niveau, idet der lægges vægt på dialog. Målene, der indgår i aftalerne, er typisk en kombination af mål, der afledes direkte fra det politiske niveau og mål, som er fastlagt af ledere og medarbejdere i de enkelte tilbud. Processen forløber sideløbende med budgetprocessen og er koordineret hermed, således at budgetmålene også er inkluderet i aftalen. Alle aftaleholderne deltager én gang årligt i et dialogmøde med kommunalbestyrelsen, hvor resultatopnåelse præsenteres og diskuteres. Kommunen ledes værdibaseret, forstået på den måde, at der i de overordnede politikker er formuleret et eksplicit værdigrundlag for de faglige områder. På handicapområdet er det udtrykt på følgende måde:

Det værdigrundlag som Betas handicappolitik bygger på, kan udtrykkes ved følgende grundlæggende værdier: Den enkelte borger i centrum; lige muligheder for alle; et liv så tæt på det almindelige som muligt; inklusion - et åbent lokalsamfund med plads til alle.

(Handicappolitik, 2009)

De forskellige områders politikker fungerer som værdisystemer og forankrer tilbuddenes indsatser i en fælles retning. Selvom aftalesystemet er bygget op om dialog, er det også klart, at formålet er at måle resultater og at kunne følge op på, om den politiske fastlagte retning følges. Derfor fremstår dialogsystemet som et diagnostisk styringssystem, der sikrer, at de enkelte organisatoriske enheder opererer inden for de rammer, der er sat med værdisystemet. Socialudvalget har udarbejdet en hensigtserklæring for handicapområdet, og der er udarbejdet en omfattende handlingsplan:

At der er tale om en ramme, betyder, at politikken i form af værdier og målsætninger angiver den overordnede ramme, inden for hvilken politikerne ønsker, at indsatsen på området skal foregå. Politikken angiver ikke konkrete forslag til, hvorledes politikken skal implementeres i kommunens samlede indsats på området.

(Handleplan for handicappolitik, 2009) 
Den politiske erklæring såvel som handlingsplanen er overordnet og fungerer som en del af værdistyringssystemet og er guidende for medarbejdernes dialog med og inddragelse af klienter og pårørende. Planen indeholder i særdeleshed ikke angivelser af fremtidige behov, målgrupper eller behov for nye tilbud og interventioner, men er primært fokuseret på at adressere de øjeblikkelige udfordringer fremfor at sikre den langsigtede udvikling.

I flere af interviewene lagde lederne vægt på resultatmålene i de dialogbaserede aftaler, og det blev fremhævet, at aftaleholderne havde stor indflydelse, når målene blev fastlagt. Der blev også udtrykt opbakning til retningen, der med handlingsplanen var sat af socialudvalget og direktionen, om end de overordnede målsætningerne, der var formuleret i handlingsplanen, sædvanligvis ikke blev fremhævet, når vi spurgte til de centrale målsætninger. Derimod blev der lagt stor vægt på de lokale målsætninger og visioner, der drev de enkelte tilbud. Eksempelvis fremhævede lederen af et kombineret botilbud og beskyttet beskæftigelse, at:

Vi skaber individuelle og kreative løsninger, der beror på fællesskabets ressourcer og kompetencer. Hver afdeling har en tydelig profil med afsæt i en stærk kultur og faglig identitet. Samarbejdet - både med eksterne samarbejdspartnere og internt - er baseret på dialog og involvering, så alle bedst muligt kan bidrage til opfyldelsen af vores mål.

(Vision Sløjfen Bo- og Aktivitetstilbud, 2012)

De lokale formuleringer var imidlertid i overensstemmelse med de overordnede værdier og målsætninger, hvilket betød, at den overordnede vision blev konkretiseret i forhold til tilbuddet og målgruppen. Det blev i interviewene fremhævet, at det var vigtigt at kunne have lokale visioner og frihedsgrader til som forstandere at kunne sætte retning, og at både kommunalbestyrelse og direktion bakkede op om det, under forudsætning af, at det var afstemt med den retning, direktionen havde udstukket. Lederne lagde ved udviklingen af den lokale vision vægt på at kunne involvere medarbejdere og dermed sikre, at tilbuddenes karakteristika var indeholdt $\mathrm{i}$ visionen, herunder at den faglige tilgang og de anvendte metoder blev tilrettelagt $\mathrm{i}$ overensstemmelse med målgruppens behov, samtidig med at der kunne være dialog med direktionen om prioriteringerne:

Det er en frihedsgrad, at vi selv kan tilrettelægge vores visioner og fagligheden. Vi kan diskutere det med sekretariatet, og vi kan få en udfordring i forhold til 
handleplaner osv., men der handler det om at være skarp i forhold til, hvad vi kan levere og ikke mere end det. Der er nogle faktorer, som sætter grænser, og den økonomiske ramme er, hvor den er, og så må vi gøre det inden for den ramme, men retten til at sætte visionen det har vi frihedsgrader til.

(Forstander 2)

\section{Budgetstyring og fagprofessionelle værdier}

Sammen med det dialogbaserede aftalesystem har budgetstyringen en central rolle i Beta, idet denne allokerer ressourcer, overvåger forbruget og sikrer løbende opfølgning igennem året, med henblik på at sikre budgetoverholdelse Budgetstyringen er dermed som udgangspunkt et diagnostisk styringssystem eksplicit tilrettelagt med henblik på at sikre en fremdrift i forhold til planer og budgetter samt skabe forudsigelighed i den økonomiske målopfyldelse:

Men vi er ret skrappe i vores økonomistyring, det tror jeg også du vil høre rundt omkring. Det er lige på og hårdt. Hvis der er en aftaleholder, der siger: "Vi har en forventning om, at vi får overskredet med mere end 4\%", så sætter vi en handleplan i gang. Og det gør vi med det samme. Den handleplan, der skal økonomikonsulenten, en af mine kollegaer her i fagteamet, egentlig have en fornemmelse af, hvor det er henne af på de enkelte institutioner. Men ellers er det aftaleholderens pligt fem dage inde i den nye måned at reagere, hvis det er, at de overskrider (Budgetchef).

Budgetterne for de enkelte tilbud er fastlagt ved detaljerede beregninger af behovene i forhold til de enkelte målgrupper samt i henhold til takstbekendtgørelsens bestemmelser, hvor den forventede belægningsproces på tilbuddene indkalkuleres i årsbudgettet. Da der bevilges ressourcer til tilbuddene efter gennemsnitlige omkostningsbestemte takster, har tilbuddene klare incitamenter til at sikre fleksibilitet og udnytte ledig kapacitet. Det var ligeledes markant, at det centrale budgetkontor arbejdede tæt sammen med tilbuddene:

[...] vi prøver at arbejde meget konstruktivt og positivt omkring det at være bindeled i organisationen. Og vi er selvfølgelig også delvist kontrollanter, men vi er først og fremmest samarbejdspartnere. Det synes jeg er et meget vigtigt signal at sende ud. Og en samarbejdspartner kan også godt komme med kritik.

(Økonomikonsulent)

Forstanderne lægger stor vægt på budgetoverholdelse, som de opfatter som en integreret del af at drive et kvalitetstilbud. F.eks. fremhævede en leder at: 
Vi overholder lovgrundlaget, og vi er ansat af kommunalbestyrelsen, som bestemmer, hvad vi skal gøre det inden for. Man kan ikke bare sige, at vi er her for borgerne, så nu skal de have mere end der er penge til. Jeg vil gerne være med til at finde på ideer og måder at gøre det bedre på, så borgerne får mest muligt.

(Forstander 3)

Myndighedsafdelingen, der står for visitation, har et fast budget, hvilket indebærer, at der i løbet af budgetåret ikke reguleres for ændringer i demografi eller behov. Det indebærer, at en forøgelse i antallet af klienter vil forøge presset på den faste visitationsramme, hvorfor det er nødvendigt løbende at sikre, at de ydelser, der tildeles, svarer til behovene, men heller ikke overstiger, hvad der er nødvendigt. Da der var forventning om et forøget antal borgere i målgrupperne for sociale indsatser, var denne afbalancering mellem behov og ressourcer af afgørende betydning:

Det stemmer ikke overens med den tilgang og afgang der er. De handicappede bliver ældre og ældre, så afgangen bliver mindre. Vi har til gengæld færre trafikuheld. Vi har været heldige, at vi har unge med hjælp 24 timer i døgnet som flytter, men der er stigende tilgang.

(Socialchef)

Myndighedslederen lagde også stor vægt på at kunne styre budgettet og have både økonomisk og faglig information til rådighed. Dette omfattede både detaljeret information om klienterne på individniveau, hvad angår indsatser og omkostninger, og sammenligning af priser imellem både kommunens egne tilbud og eksterne tilbud. Overblikket over den økonomiske såvel som ikkeøkonomiske information skabes ved regneark, som Myndighedslederen, der har en baggrund inden for regnskab og administration selv har udviklet, fordi det var nødvendigt: "Der var ikke styr på data. Vi vidste ikke, hvad for nogle borgere, vi havde med at gøre! Vi vidste ikke, hvad det kostede. Vi kendte ingenting." (Myndighedsleder).

Det blev endvidere ved interviewet med myndighedslederen fremhævet, at det var afgørende at have styr på, hvordan ressourcerne var fordelt i organisationen, hvis det skulle forhindres, at omkostningerne hele tiden steg. Dette overblik skulle være så præcist som muligt, så data kunne anvendes af ledelsen til at sammenligne omkostninger og kvalitet i forhold til de enkelte målgruppers behov på tværs af tilbud, og når der skulle prioriteres og responderes på f.eks. nye målgruppers behov. 
Vi bliver nødt til at vide, hvad det er for nogle borgere, vi har rundt omkring i landet og se... Nogen har det rigtig fint. Vi har også nogle stykker, hvor vi siger, at de skal da flyttes. Men det er det igen. Det er det med synligheden. Der kommer virkelig andre øjne på og ser, hvordan borgerne går og har det. Det synes jeg er dejligt.

(Myndighedsleder)

For at kunne holde omkostningerne i ro, overholde lovgivning og sikre at politiske fastlagte servicestandarder blev overholdt samt imødekomme klienternes behov, var der i det daglige arbejde fokus på systematiske og korrekte afgørelser. Dette blev sikret gennem en fagprofessionel styring, der som grænsesystem sikrede, at sagsbehandlere havde klarhed over, hvad der var forventet af dem, når klienters behov blev udredt. Der var derfor fastlagt klare grænser for de ydelser, der kunne visiteres til ud fra faglige standarder. Dermed sikredes konsistens og ensartethed i sagsbehandlingen samt ved visitationen af ydelser.

Det faglige grænsesystem omfattede også anvendelsen af et visitationsudvalg, hvor myndighedslederen var formand, og hvor alle større indsatser skulle bevilges. Det drejede sig i særdeleshed om botilbud, hvor visitationen var baseret på en nøje vurdering af kvalitet og pris. For at styrke kvaliteten i sagsbehandlingen var der indført standardiserede udredningsmetoder, der sikrede, at alle problemstillinger blev taget i betragtning. Udredningsmetoderne var baseret på voksenudredningsmetoden i kombination med kvalitetsstandarder, der angav rammer for serviceniveauet i Beta. Udover at skabe rammer for mulighedsafsøgningen interagerede det fagprofessionelle grænsesystem med budgetstyringen, idet de væsentligste faktorer, der påvirker udgifterne langsigtet, netop er de faglige visitationsbeslutninger.

I det hele taget var den faglige opfølgning blevet en fast indarbejdet del af de daglige arbejdsrutiner. Alle borgere på botilbud uden for kommunen blev eksempelvis hvert år besøgt af en sagsbehandler med henblik på at evaluere kvaliteten og tilstrækkeligheden af indsatsen. Myndighedslederen pointerede, at denne opfølgning, var én af de vigtigste opgaver, og fremhævede, at opfølgningen ofte gav anledning til ændringer i indsatserne, og at det typisk var i retning af reduktion i indsatser og dermed også reduktion i udgifter. På denne måde blev det sikret, både at klienterne modtog ydelser af høj kvalitet, samtidig med at kommunen kun betalte for de ydelser, der var behov for: 
Ikke nødvendigvis skrue ned, men følge borgeren. Er det her stadigvæk det rigtige billede? Er det her stadigvæk det rigtige tilbud? Det synes jeg er vigtigt.

(Myndighedsleder)

Ledelsen i socialafdelingen lagde vægt på, at sagsbehandlerne både tog omkostninger og indsatsernes kvalitet i betragtning, når der blev visiteret til ydelser, og at det blev sikret, at der også var budgetmæssige ressourcer til at imødekomme behovet hos andre borgere. Denne opmærksomhed var skabt i en længere udvikling, men var nu bredt accepteret i organisationen, og socialchefen fremhævede, at denne stramme ressourcestyring faktisk var grundlaget for et øget fagprofessionelt handlerum:

For mig er økonomistyring noget, der starter med høj faglighed, og det har faktisk givet en højere faglighed, at vi har fået fokus på styring. Styring understøtter, at vi bliver skarpere fagligt. Vi har fundet pengene, og jeg kan mærke at socialrådgiverne er blevet helt anderledes optaget af det og stiller spørgsmålstegn ved f.eks. firmaer, der leverer ydelser, og så siger de: Dem vil vi ikke bruge, de leverer ikke godt nok til prisen! Vi har fået skabt et fællesskab.

(Socialchef)

\section{Interaktiv styring af vilde problemer}

Både det dialogbaserede aftalesystem og budgetstyringen er centrale i Beta, men det er primært budgetstyringen, der i sin brug træder frem som et interaktivt styringssystem, hvor ledere på flere niveauer er personligt involveret, engagerer sig i mødeaktiviteter og løbende skaber diskussioner og udfordrer problemer og løsninger. Til forskel herfra er det dialogbaserede aftalesystem forankret hos den politiske ledelse, og selvom de enkelte forstandere løbende monitorerer deres resultatmål, er der ikke den samme fleksibilitet og dialog i den administrative ledelsesstreng, som det ses ved brugen af budgetstyringen. Da budgetstyringen integrerer de faglige og økonomiske målsætninger, er det her de virkelige dilemmaer mellem kvalitet, ydelsers tilstrækkelighed, budgetoverholdelse og fremadrettede behov, som de vilde problemer skaber, skal adresseres.

Dialogen i den interaktive styring starter i Beta ofte på ledelsesmøderne, hvor både socialchef, myndighedsleder og forstandere deltager. Emnerne, der diskuteres på ledermøderne bringes videre ud i organisationen gennem ledelseshierarkiet, og diskuteres på møder mellem medarbejdere og ledere i de enkelte dele af organisationen. Der er på disse møder en åben dialog 
og socialchefen fremhæver, hvordan han sikrer sig, at alle relevante emner kommer på dagsorden, samtidig med at alle ledere opfordres til at deltage aktivt og præsentere de bekymringer og udfordringer, som de støder på:

De er begyndt at tænke i helheder, at det ikke kun er dem selv det hele drejer sig om, men at de er en del af en større kommune efterhånden. Og det at den ene ikke kan løse... Jamen kan man så hjælpe hinanden på tværs imellem institutionerne! Der er kommet mange ting på banen.

(Myndighedsleder)

Da vi gennemførte interviewene, var der især opmærksomhed om at identificere ændringer i målgruppernes behov, ændringer i tilgangen af borgerne samt nye behov og problemstillinger, der fremadrettet ville kræve forøgede indsatser. Der var på disse møder fokus på, hvordan der kunne responderes med fleksibilitet og nye løsninger, så mere individuelt tilrettelagte løsninger kunne håndteres af kommunens egne tilbud frem for at købe ydelser fra private leverandører, regioner eller andre kommuner. Effekten af dette fokus og de intensive drøftelser omkring denne tilgang var allerede tydelige under interviewene med forstanderne. Fremfor at diskutere, om det er muligt at optage nye målgrupper, fokuserer tilbuddene på, hvordan det kan lykkes:

Jeg synes, vi søger en høj grad af specialisering, men du kan ikke gøre det inden for et enkelt område og sige, at vi er rigtig gode til de her [borgere]. Den tid er død. Men vi skal specialisere os. Vi skal være gode til det vi gør, og vi er specialister i individuelt tilrettelagt tilbud.

(Forstander 1)

Den interaktive styring skaber løbende dialog, og forstanderne beskriver, hvordan de løbende tilpasser og laver justeringer i indsatserne, både i forhold til de enkelte borgere og i forhold til tilbuddets sammensætning. Det er her både et spørgsmål om fleksibilitet i forhold til efterspørgslen, og om at holde et omkostningsniveau, hvor taksterne er konkurrencedygtige:

Jamen vi løser meget, og den kultur vil jeg gerne have skal gennemsyre hele organisationen. Og det er jeg i gang med at lave omstilling til, fordi det er vores overlevelse, og det er vores måde at sikre så god en drift som muligt for både borgere og personale... For et år tilbage barberede vi omkring halvanden million af en opgave vi fik, som blev løst af regionen, som vi tog ind. Det er mange penge for kommunen, og det betyder noget for alle stederne. Ikke bare for vores organisation, 
men for kommunen som helhed. Jo mere vi hver især kan rationalisere på en ordentlig måde, jo flere penge. Altså færre besparelser vil vi blive ramt af. Vi er jo nødt til at forstå, at vi er en del af en større helhed.

(Forstander 1)

Forstanderen fremhæver, hvordan hun er i dialog med både socialchefen og de andre forstandere for at være fleksibel i forhold til ændringer i behov, både i målgruppen og i forhold til kommunens målsætninger. I interviewet lagde lederen også vægt på, at de emner, der diskuteres på ledermøderne, ofte bliver fulgt op med møder mellem socialchefen og den enkelte forstander for at diskutere konsekvenserne for det specifikke tilbud. Dette gør problemstillingerne konkrete og relevante, samtidig med at socialchefen ved sin involvering er med til at forme afsøgningen af de strategiske muligheder, der er funderet i de enkelte borgeres perspektiv: "Vi skal rette os efter, hvordan vi kan støtte dem i, hvordan deres liv skal være. Det er meget nyt. Før var det meget borgeren, der skulle indrette sig efter stedet. Nu er det omvendt.” (Forstander 2).

Myndighedslederen, som også deltager på ledelsesmøderne, har gennem tæt dialog og møder med socialchefen fået forøget opmærksom på, at der både skal skabes resultater for borgerne og ske en løbende tilpasning af ressourcerne til de aktuelle behov. Myndighedslederen var derfor løbende og meget detaljeret involveret i det faglige arbejde i afdelingen. Dette var både for at sikre dialog om udviklingen i f.eks. borgeres funktionsevne, for at sikre, at der blev fulgt løbende op på de enkelte sager og for at sikre, at klientens behov løbende blev imødekommet, samtidig med at et rehabiliteringsfokus gennemsyrede alle ydelser:

Var du først smidt ind i en institution, så smed man nøglen væk, og så blev du der, indtil du blev båret ud. Sådan en tilgang har jeg slet ikke til det. Jeg vil gerne have, at $75 \%$ af dem, vi arbejder med både på psykiatri og handicap, der er der en eller anden form for progression. Der er et eller andet, der kan udvikles. Der er nogen, der ikke kan - det ved jeg godt. Men de kan så have en anden.... Men der er et eller andet i os alle sammen og måske specielt psykiatri. Selvfølgelig kan vi det!

(Myndighedsleder)

Efter en række år, hvor budgetterne havde været overskredet, resulterede 2011 i et mindreforbrug, som socialudvalget efter indstilling fra socialchefen og myndighedslederen besluttede skulle anvendes til, at investering i udviklingen af nye tilbud med øget fokus på rehabilitering: 
Vi kigger lidt mere på forebyggelse også omkring det sociale område. Der siger vi, at vi laver denne her indsats nu, selvom det ikke er strengt nødvendigt, men ved om et år, så sparer vi pengene. Og borgeren får måske også noget mere værdi ud af det her. Får en bedre oplevelse! Får et bedre liv! Så den kasket har vi jo også på. Det er ikke kun økonomi her, og det er egentlig lidt fedt at have den oplevelse nu, fordi vi har råd til at tænke sådan.

(Myndighedsleder)

\section{F. Diskussion}

Lederne i Beta er løbende involveret i at adressere de vilde problemer, som karakteriserer socialområdet, med udgangspunkt i budgetstyringen. For at sikre en stram budgetstyring er der især fokus på den kortsigtede budgetopfølgning, men det sker med et samtidigt blik for den langsigtede udgiftsudvikling. Både som Kominis \& Dudau (2012) samt Kloot (1997) konkluderede kan uforudsigelighed og omgivelsesusikkerhed betyde, at budgetter vil blive anvendt mere intensivt og indgå som centrale elementer i et interaktivt styringssystem. Dette er også, hvad studiet af Beta viser, idet kommunen i årene forinden både havde haft svært ved at forudsige udviklingen i udgifterne og at undgå merforbrug på socialområdet. I konsekvens heraf var processerne omkring den finansielle styring blevet styrket, og der var kommet mere fokus på en forudsigelighed i den økonomiske udvikling. I denne forbindelse var budgetlægningen et centralt værktøj, men i den interaktive brug får det en rolle, der ikke blot er begrænsende, men sikrer en ledelsesmæssig opmærksomhed på områdets indbyggede dynamikker, så de strategiske usikkerheder om den fremtidige udvikling kan håndteres.

Selvom en ét-årig budgetproces i sin natur er kortsigtet, var det markant, at den interaktive brug af budgetstyring skabte et længere perspektiv, ikke kun hvad angår usikkerheden om de fremtidige målgrupper, men også ved at sikre den organisatoriske tilpasningsdygtighed til nye opgaver og ved at have fokus på kapacitetsudnyttelse og takstniveau, så tilbuddene også fremadrettet er konkurrencedygtige. Således var der ledelsesmæssig involvering på flere niveauer i håndteringen af de økonomiske konsekvenser af de løbende ændringer.

For at håndtere de vilde problemer var det i Beta nødvendig at være kreativ og finde nye løsninger. Ligeledes var der brug for at skabe nye muligheder, når det skulle sikres, at belægningsprocenten i tilbuddene var tilstrækkelige høje, så taksterne kunne være 
konkurrencedygtige. Dette behov for innovation var integreret i den interaktive anvendelse af budgetstyringen. Studiet af Beta indikerer dermed, at styringsprocesser kan fremme kreativitet i den offentlige sektor og skabe rum for innovation og læring. Specielt var det markant, at økonomistyringen både styrkede den fagprofessionelle dømmekraft og bidrog til at opnå en styrbarhed i forhold til budgetoverholdelse. Der var ikke i de interview, vi gennemførte, indikation af, at styring blev opfattet som begrænsende for at opnå faglige resultater, hvilket er en modsætning til den del af litteraturen (f.eks. Bruijn 2007; Dooren et al. 2015), der især fremhæver uhensigtsmæssighederne ved styring.

Ledernes positive vurdering af budgetstyringen skal formodentlig ses i sammenhæng med både den klare retning, som værdistyringen skaber og de fagligt funderede grænsesystemer, som ganske vist begrænser handlerummet, men gør det med udgangspunkt i de faglige normer og værdier, således at styringen opfattes som understøttende frem for kontrollerende (Andersen \& Pedersen 2014). Ligeledes giver det dialogbaserede aftalesystem lederne store frihedsgrader, men også forpligtigelser til at styre økonomien i deres egne afdelinger.

På socialområdet er det nødvendigt med et fokus på de enkelte sager og den iboende kompleksitet - de vilde problemer - som disse indebærer. Dette understøttes af budgetstyring, der forener den fagprofessionelle vurdering og opfølgning på individniveau med den organisatoriske budgetoverholdelse. Det er en del af den løbende økonomiske og faglige styring at granske de enkelte sager for at sikre, at klienterne får præcist de ydelser, de har ret til og behov for. Hverken mere eller mindre. Når de kortsigtede budgetkrav realiseres, sikres samtidig ressourcer til at imødekomme de udfordringer, der venter forude. Kan der frigøres ressourcer i de enkelte sager eller ligefrem realiseres et mindreforbrug på området, kan dette geninvesteres, så der kan udvikles løsninger til fremtidens behov.

Ud fra en teknisk betragtning, er der ikke noget usædvanligt i, at der lægges budgetter og følges op på dem, eller at der holdes møder. Det afgørende for den succesfulde anvendelse i Beta er, at der er udgangspunkt i de strategiske målsætninger og de pejlemærker, der bæres af værdistyringen. Ligeledes er det anvendelsen af informationen fra budgetsystemet, der betyder, at det transformeres til et interaktivt styringssystem, hvilket Simon udtrykte ved, at ledere "personally involve themselves in the decision activities of subordinates" (Simons 2000, p. 216). Den underliggende strategiske variabel er strategiske usikkerheder, som Simon (2010, p. 158) 
refererer til som "the threats and contingencies that could invalidate assumptions underpinning the strategy". Ved at anvende budgetstyringen interaktivt signalerer ledelsen i socialafdelingen deres præferencer for, hvilke løsninger, der skal vælges og i en dialog og med fleksibilitet findes nye vej at gå.

Durant \& Legge (2006) har i relation til vilde problemer anført, at traditionelle styringssystemer er utilstrækkelige og derfor skal kombineres med andre styringsformer, der kan fremme fleksibilitet, refleksivitet og læring. Studiet af Beta viser, at den underliggende dynamik og usikkerhed på socialområdet faktisk kan adresseres ved en traditionel budgetmodel, men det kræver, som Simons (1995, p. 59), at informationen anvendes interaktivt. Derfor er spørgsmålet om, hvorvidt budgettering fremmer eller hæmmer fleksibilitet et spørgsmål om brugen af information fremfor om budgetteringens tekniske egenskaber er optimale.

Rittel og Webber (1973) beskrev en række eksempler på offentlige indsatser, der kunne karakteriseres som vilde problemer, men de graduerede ikke begrebet, således at nogle situationer kunne være mere eller mindre vilde. Empiriske studier har senere udfordret den klassifikation og foreslået nuanceringer i adresseringen af vilde problemer ved at foreslå, at graden af vildskab kan gøre det muligt at afgrænse problemstillinger, således at disse kan løses (Head \& Alford 2015) eller tæmmes, for nu at bruge en tilsvarende terminologi. Studiet af Beta indikerer, at socialområdet ganske vist iboende er karakteriseret ved vilde problemer, men at det også består af en række processer, hvor en integreret anvendelse af styringssystemer og fagprofessionelle håndteringer af udfordringerne kan bidrage til at strukturere de vilde problemer, så de kan adresseres, og måske tæmmes. Graden af vildskab blev også afspejlet ved, at nogle udfordringer var både velunderbyggede og kendte på forhånd, således at der inden for rammerne af styringssystemerne kunne udarbejdes planer i tilstrækkelig god tid - men der var også udfordringer, og i særdeleshed enkeltsager, der var uforudsigelige, og hvor det var vanskeligere at vide, hvad de rigtige løsninger var, og vanskeligere at være forberedt.

De begrænsende styringssystemer udfordres af socialområdets kompleksitet og uforudsigelighed. Budgetter er økonomiske kvantificeringer af handlingsplaner, og jo vanskeligere det er at planlægge, jo vanskelige bliver det at lægge budgetter, som er egnede til realisering. Men netop ved den interaktive brug af budgetstyringen udnyttes dynamikken til at skabe en løbende balancering mellem de konfliktende målsætninger, så kreativitet og læring fremmes. Vi 
interviewede i Beta kort tid efter, at stram styring nationalt var kommet på socialområdets dagorden, men en række af udfordringerne i forhold til budgetoverholdelse var tilsyneladende løst i Beta, og der blev i kommunens strategier og planlægning taget udgangspunkt i at budgetterne også fremover kunne holdes i balance. Der blev ikke givet udtryk for, at det øgede fokus på budgetoverholdelse havde været blokerende for at arbejde med faglige målsætninger og udviklingen af kvalitet i de sociale tilbud.

I et studie af det britiske Every Child Matters-program konkluderede Kominis \& Dudau (2012), at den forøgede kompleksitet og dynamik på socialområdet havde betydet, at ansvarsgrænserne mellem aktører var blevet mere slørede, og at 'traditionel' styring med mål og rammer er mest egnet, når der kan identificeres klare og præcise resultatindikatorer og etableres sammenlignelige standarder, der kan benchmarkes. I Beta responderes på tilsvarende udfordringer ved at øge klarheden i målsætningerne i alle dele af styring: Værdisystemerne havde fået en klarere toning af målbarhed, og grænsesystemerne havde også skabt mere struktur og klarhed, ligesom den dialogbaserede aftalestyring også var målbaseret. Disse systemer udgjorde grundstrukturer, inden for hvilke den interaktive styring kunne udfoldes fleksibelt.

\section{G. Konklusion og perspektivering}

Overordnet set er artiklens konklusion, at økonomistyring kan understøtte, at socialområdets komplekse og vilde problemer adresseres på et fagligt grundlag, samtidig med at budgetoverholdelse og omkostningsbevidsthed styrkes. Den ofte antagne modstrid mellem styring og faglighed var ikke central, når lederne beskrev styringen i Beta. Ligeledes, hvad angår muligheden for kreativ problemløsning og udvikling af nye innovative løsninger, så blev dette ikke forhindret af den økonomiske styring. Økonomistyringen styrkede derimod fagligheden og var instrumentel for afsøgningen af nye muligheder. Nøglen til at få det til at fungere i Beta - og dermed også til at forstå, hvordan styring i praksis fungerer og kan udvikles er, at velfungerende styring er et spørgsmål om at finde en egnet balance mellem begrænsende og mulighedsskabende styringssystemer.

Litteraturen om vilde problemer beskriver generelt styringssystemer som begrænsende for problemløsningen (Blackman 2006; Head \& Alford 2015), men studiet af Beta indikerer, at styring ikke blot kan medvirke til at reducere usikkerhed og dermed påvirke graden af vildskab, men også 
at en øget anvendelse af budgetlægning, planlægning og omkostningsinformation kan forøge fremfor begrænse mulighedsrummet. Det afgørende er imidlertid, hvordan styringssystemerne anvendes. Det indebærer, at en bestemt økonomistyringsteknik, eller det at fokusere på budgetoverholdelse i sig selv, ikke vil have en bestemt og forudsigelig konsekvens for den faglige indsats på socialområdet.

Den praktiske implikation, når der tilrettelægges økonomisk styring på socialområdet er, at man skal være varsom med at overføre erfaringer med konkrete teknikker fra den ene kommune til den anden. Det er muligt, at noget fungerer eller fejler i én kommune, men konteksten for styringssystemer, strategier og politikker, samt ikke mindst den konkrete implementering af et styringssystem, i sagens natur vil være forskellig fra kommune til kommune. Derfor vil effekten af styringssystemer også være forskellig kommunerne imellem. For som praktiker at kunne udvikle ny økonomistyring er det ikke blot nødvendigt at have viden om, hvordan teknikker fungerer og kan anvendes. Man skal kende til, hvilke forudsætninger der skal være til stede for, at teknikker har bestemte konsekvenser frem for andre, ligesom man skal have viden om, hvordan økonomistyringsteknikker fungerer i kombination med hinanden. Det er mere kompliceret end bare at vide, hvordan man tilrettelægger f.eks. en budgetproces, og det kan være svært at tilegne sig denne viden uden også at have en dybere og økonomistyringsfagligt funderet viden om økonomistyringsdesign.

For studier af økonomisk styring betyder det, at djævlen ligger i detaljen. For at opnå indsigt i, hvilken form for økonomisk styring, der er velfungerende, skal styringen studeres i sin konkrete konktest, hvor ikke mindst den samlede forståelse for, hvorledes styringsinstrumenter fungerer som en samlet helhed er vigtig. Kortlægninger af styringspraksis på konkrete serviceområder (f.eks. Dalsgaard et al. 2019; Nørgaard et al. 2017) giver naturligvis et overblik over, hvilke teknikker der overordnet set er i brug, men indebærer ofte også, at teknikerne beskrives isoleret, uden at ses som et samlet kompleks af styring i den enkelte kommune, og uden at give indsigt i, hvorfor noget fungerer eller ikke fungerer. Sådanne studier har sin berettigelse og nødvendighed, og giver ny indsigt, hvis man ikke har kendskab til design af økonomistyring. For at skabe indsigt i hvordan økonomiske styring kan etableres, er der dog i højere grad brug for studier af den konkrete praksis i sin kontekst. 
Hvis man for isoleret ser på, om teknikker anvendes eller ej, giver det ikke nødvendigvis et brugbart svar på, om man i den enkelte kommune skal anvende en teknik - og giver heller ikke hjælp til, hvordan den skal anvendes. Ofte tager litteraturen om økonomistyring på socialområdet, hvad enten den er forskningsbaseret (f.eks. Anslem \& Gendron 2019; Chow et al. 2019) eller mere beskrivende (f.eks. Kjærgaard et al. 2016), implicit udgangspunkt i, at der vil være modstrid mellem faglige hensyn og resultater og økonomisk styring og styrbarhed. Vi finder i lighed med Schrøder (2019), at sagsbehandlere på området kan udvikle kompetencer og praksisformer, der forbinder økonomiske hensyn og faglige hensyn.

Enkelte casestudier er naturligvis begrænsede ved at sammenhænge og effekter kan være anderledes i andre cases. Studiet af Beta viser, at sagsbehandlere ikke blot kan udvikle gode og egnede styringskompetencer, men som i Beta allerede har det. Studier af flere kommuner vil kunne afdække om denne konklusion kan generaliseres. Spørgsmålet er, om ikke økonomiske og faglige hensyn allerede i praksis er integrerede i de fleste kommuner? Hvis det er tilfældet, er der i højere grad behov for mere dybdegående at studere, hvad økonomiske hensyn er, således som Schrøder (2019) gør, samt hvad økonomiske hensyn i det hele tage består af. Spørgsmålet er dermed ikke, om der skal tages hensyn til økonomi i socialfagligt arbejde, eller om det vil blive accepteret, men hvordan disse hensyn i praksis tages og opfattes. Yderligere forskning på området vil derfor med fordel kunne fokusere på, hvordan og hvorfor denne integration bliver meningsfuld, samt hvilken form for styring der kan understøtte en faglig meningsskabelse.

Vi interviewede ikke medarbejdere, idet LOC-begrebsrammen fokuserer på styring fra et topledelsesperspektiv, hvilket Simons (1990) definerer som "those responsible for ensuring that strategies are formulated and implemented”. For at kunne konkludere mere sikkert om, hvorledes den socialfaglige praksis påvirkes af styringen, kan der være behov for også at interviewe medarbejdere, hvilket vil være en anbefaling til yderligere forskning på området. Vores fokus på mellemledere indikerer imidlertid også, at netop mellemledere har en central rolle som oversættere og mediatorer (Balugon \& Johnson, 2004), når politikker og styringstag implementeres. Forskning har desuden vist, at mellemledere er centrale som forandringsagenter og som koordinatorer af medarbejderens aktiviteter i forhold til slutbrugerne (Dutton et al., 1997). For at opnå en bedre forståelse for, hvordan økonomisk styring kan tilrettelægges, kan det derfor være vigtigt at studere, hvordan mellemledere forstår og skaber mening ud af centralt fastlagte 
politikker samt oversætter disse til organisatoriske praksisser, der er meningsfulde for medarbejderne.

Studier af vilde problemers håndtering har sjældent direkte fokus på den økonomiske styring, men med et stigende behov for stram budgetstyring kan de vilde problemer næppe adresseres i praksis eller studeres forskningsmæssigt, uden at den økonomiske dimension tages eksplicit i betragtning; og måske budgetoverholdelse blot skal ses som endnu en dimension af vildskaben. Studiet indikerer, at socialfaglighed og komplekse problemer ikke eksisterer isoleret fra den økonomiske styring. Ligesom problemer kan forværres af dårlig økonomisk styring, kan problemer også reduceres ved god økonomisk styring.

\section{Referencer}

Abernethy, M. A. \& Brownell, P. (1999), “The role of budgets in organizations facing strategic change: an exploratory study", Accounting, Organizations and Society, Vol. 24 No. 3, pp. 189-204. https://doi.org/10.1016/s0361-3682(98)00059-2

Aguinis, H., \& Pierce, C. A. (2008), "Enhancing the relevance of organizational behaviour by embracing performance management research”, Journal of Organizational Behavior, Vol. 29 No. 1, pp. 139-145. https://doi.org/10.1002/job.493

Ahrens, T. \& Ferry, L. (2015), "New Castle City Council and the grassroots: accountability and budgeting under austerity”, Accounting, Auditing and Accountability Journal, Vol. 28 No. 6, pp. 909933. https://doi.org/10.1108/aaaj-03-2014-1658

Alford, J. \& B. W. Head (2017), "Wicked and less wicked problems: a typology and a contingency framework”, Policy and Society, Vol. 36, no. 3, pp. 397-413.

https://doi.org/10.1080/14494035.2017.1361634

Amirkhanyan, A. A., Kim, H. J., \& Lambright, K. T. (2014), “The performance puzzle:

Understanding the factors influencing alternative dimensions and views of performance", Journal of Public Administration Research and Theory, Vol. 24 No. 1, pp. 1-34.

https://doi.org/10.1093/jopart/mut021

Amslem, T. \& Gendron, Y. (2019), "From emotionality to the cultivation of employability: An ethnography of change in social work expertise following the spread of quantification in a social enterprise", Management Accounting Research, Vol. 43, pp. 39-55.

https://doi.org/10.1016/j.mar.2018.06.001 
Andersen L.B. \& L.H. Pedersen (2014), Styring og motivation i den offentlige sektor, København: Jurist- og Økonomforbundets Forlag.

Balogun, J. \& Johnson, G. 2004. "Organizational restructuring and middle manager sensemaking”, Academy of Management Journal, Vol. 47 No. 4, pp. 523-549. https://doi.org/10.2307/20159600 Batac, J. \& Carassus, D. (2009), "Interactions between control and organizational learning in the case of a municipality. A comparative study with Kloot (1997)", Management Accounting Research, Vol. 20, pp. 102-1 16. https://doi.org/10.1016/j.mar.2008.11.001

Bedford, D.S. (2015), "Management control systems across different modes of innovation: Implications for firm performance”, Management Accounting Research. Vol. 28, pp. 12-30. https://doi.org/10.1016/j.mar.2015.04.003

Bedford, D.S., Malmi, T. \& Sandelin, M. (2016), "Management control effectiveness and strategy: An empirical analysis of packages and systems", Accounting, Organizations and Society, Vol. 51, pp. 12-28. https://doi.org/10.1016/j.aos.2016.04.002

Berry, A. J., Coad, A. F., Harris, E. P., Otley, D. T., \& Stringer, C. (2009), "Emerging themes in management control: A review of recent literature", The British Accounting Review, Vol. 41 No. 1, pp. 2-20. https://doi.org/10.1016/j.bar.2008.09.001

Bisbe, J. \& Otley, D. (2004), "The effects of the interactive use of management control systems on product innovation", Accounting, Organizations and Society, Vol. 29 No. 8, pp. 709-737.

https://doi.org/10.1016/j.aos.2003.10.010

Blackman, E., Elliot, T., Greene, A., Harrington, B. Hunter, D. J. Marks, L., Mckee, L. \& Williams, G. (2006), "Performance Assessment and Wicked Problems: The case of Health Inequalities”, Public Policy and Administration, Vol. 21 No. 2, pp. 66-80.

https://doi.org/10.1177/095207670602100206

Blom-Hansen, J., Ibsen, M., Juul, T. \& Mouritzen, P.E. (2012), Fra sogn til velfardsproducent: Kommunestyret gennem fire årtier, Odense: Syddansk Universitetsforlag.

Bracci, E, Humphrey, C., Moll, J. \& Steccolini, I. (2015), "Public sector accounting, accountability and austerity: more than balancing the books?", Accounting, Auditing and Accountability Journal, Vol. 28 No. 6, pp. 878-908. https://doi.org/10.1108/aaaj-06-2015-2090

Bracci, E. \& Llewellyn, S. (2012), "Accounting and accountability in an Italian social care provider: Contrasting people-changing with people-processing approaches”, Accounting, Auditing and Accountability Journal, Vol. 25 No. 5, pp. 806-834. https://doi.org/10.1108/09513571211234268

Broadbent J. \& Laughlin, R. (2009), "Performance management systems: A conceptual model”, Management Accounting Research, Vol. 20, pp. 283-295. https://doi.org/10.1016/j.mar.2009.07.004 Bruijn, H. de. (2007). Managing Performance in the Public Sector. Oxon: Routledge. 
Bukh, P. N. \& A. K. Svanholt (2019a), Managing and controlling wicked problems: Evidence from a Danish Municipality. Working Paper, Institut for Økonomi og ledelse, Aalborg Universitet. Bukh, P. N. \& A. K. Svanholt (2019b), Empowering middle managers in social services using management control systems, Working Paper, Institut for Økonomi og ledelse, Aalborg Universitet.

Chenhall, R. H. (2007), “Theorising Contingencies in Management Control Systems Research”, in C.S. Chapman, A. G. Hopwood and M.D. Shields (Eds.), Handbook of Management Accounting Research, Amsterdam: Elsevier.

Chow, D.S.L., Greatbatch, D. \& Bracci, E. (2019), "Financial responsibilisation and the role of accounting in social work: challenges and possibilities", British Journal of Social Work (under udgivelse). https://doi.org/10.1093/bjsw/bcz062

Cuganesen, S. \& Donovan, J. (2011), "Investigating the links between management control approaches and performance measurement systems", Advances in management accounting, Vol. 19, pp. 173-204. https://doi.org/10.1108/s1474-7871(2011)0000019014

Cuganesan, S., Guthrie, J. \& Vranic, V. (2014), "The riskiness of public sector performance measurement: a review and research agenda", Financial accountability and management, Vol. 30 No. 3, 279-302. https://doi.org/10.1111/faam.12037

Dalsgaard, V., Lemvigh K. \& Panduro, B. (2019), Det specialiserede voksenområde: Inspiration til Styring, VIVE, København.

Deschamps, C. (2019). "Stages of management control in large public organizations: from top to frontline managers", Journal of Management Control (under udgivelse).

https://doi.org/10.1007/s00187-019-00282-Z

Devaney, J \& Spratt, T. (2009), “Child abuse as a complex and wicked problem: Reflecting on policy developments in the United Kingdom in working with children and families with multiple problems", Children and Youth Services Review, Vol. 31, pp. 635-641.

https://doi.org/10.1016/j.childyouth.2008.12.003

Di Francesco, M. \& Alford, J. (2016), "Budget Rules and Flexibility in the Public Sector: Towards a Taxonomy”, Financial Accountability and Management, Vol. 32 No. 2, pp. 232-256.

https://doi.org/10.1111/faam.12087

Dooren, W. V., G. Bouckaert \& J. Halligan, (2015), Performance Management in the Public Sector, 2. udgave, London: Routledge.

Durant, R. F. \& Legge Jr., J. S. (2006), “'Wicked Problems’ Public Policy, and Administrative Theory. Lessons from the GM Food Regulatory Arena”, Administration and Society. Vol. 38 No. 3, pp. 309-334. https://doi.org/10.1177/0095399706289713 
Dutton, J., Ashford, S., O’Neill, R.M., Hayes, E. \& Wierba, E. (1997), “Reading the wind: How middle managers assess the context for selling issues to top managers", Strategic Management Journal, Vol. 18 No. 5, pp. 407-423. https://doi.org/10.1002/(sici)10970266(199705)18:5<407::aid-smj881>3.0.c0;2-j

Ferreira, A. \& Otley, D. (2009), “The design and use of performance management systems: An extended framework for analysis”, Management Accounting Research Vol. 20, pp. 263-282. https://doi.org/10.1016/j.mar.2009.07.003

Finansministeriet (2009), Analyse af takstudviklingen og incitamentsstrukturer på det specialiserede socialområde, Finansministeriet, juni 2009.

Finansministeriet, KL \& Indenrigs- og Socialministeriet (2009), Det specialiserede socialområde: redskaber til styring og prioritering, Finansministeriet, juni 2009.

Foged, S.K. (2015), "En effektevaluering af sanktioner på danske kommuners regnskaber", Økonomi \& Politik, Vol 88 No. 1, pp. 57-75.

Foged, S.K., Andersen, S.C. \& M.N. Andersen (2017), "Hvad betød den økonomiske krise for danske kommuners økonomistyring?", Politica, Vol. 49 No. 1, pp. 5-25.

Frow, N., Marginson, D. \& Ogden, S. (2010), "'Continuous' budgeting: Reconciling budget flexibility with budgetary control" Accounting, Organizations and Society, Vol. 35 No. 4, pp. 444461. https://doi.org/10.1016/j.aos.2009.10.003

Gilson, L. L., Mathieu, J. E., Shalley, C. E. \& Ruddy, T. M. (2005), “Creativity and standardization: Complementary or conflicting drivers of team effectiveness?" Academy of Management Journal, Vol. 48 No. 3, pp. 52 1-531. https://doi.org/10.5465/amj.2005.17407916

Grabner, I. (2014), "Incentive system design in creativity-dependent firms", The Accounting Review, Vol. 89 No. 5, pp 1729-1750. https://doi.org/10.2308/accr-50756

Guenther, T. W., \& Heinicke, A. (2019), "Relationships among types of use, levels of sophistication, and organizational outcomes of performance measurement systems: The crucial role of design choices”, Management Accounting Research, Vol. 42, pp. 1-25.

https://doi.org/10.1016/j.mar.2018.07.002

Hall, M. (2010), "Accounting information and managerial work", Accounting, Organizations and Society, Vol. 35 No. 3, pp. 301-315. https://doi.org/10.1016/j.aos.2009.09.003

Hansen, C.-A. (2019), "Bestiller-Udfører-Modtager-modeller (BUM) og kontraktstyring”, I

Bundesen, P. \& C.-A. Hansen (eds), Kommunal økonomisk styring på det sociale område, 4. udgave, København: Reitzels Forlag.

Head, B. W. \& Alford, J. (2015), "Wicked problems: Implications for Public Policy and Management”, Administration and Society, Vol. 47 No. 6, pp. 711-739.

https://doi.org/10.1177/0095399713481601 
Head, B. W. (2008), "Wicked Problems in Public Policy”, Public Policy, Vol. 3 No. 2, pp. 101-1 18. Henri, J-F. (2006), "Management Control Systems and strategy: A resource-based perspective", Accounting, Organizations and Society, Vol. 31 No. 6, pp. 529-558.

https://doi.org/10.1016/j.aos.2005.07.001

Hirst, G., van Knippenberg, D., Chen, C., \& Sacramento, C. A. (2011), "How does bureaucracy impact individual creativity? A cross-level investigation of team contextual influences on goal orientation-creativity relationships", Academy of Management Journal, Vol. 54 No. 3, pp. 624-641. https://doi.org/10.5465/amj.2011.61968124

Hood, C. (1989), "Public Administration and Public Policy: Intellectual Challenges for the 1990'es", Australian Journal of Public Administration, Vol. 50, pp. 346-358.

https://doi.org/10.1111/j.1467-8500.1989.tb02235.x

Hood, C. (1991) “A Public Management for All Seasons? Public Administration”, Vol. 69 No. 1, pp $3-19$.

Hood, C., Heald, D. \& R. Himaz, eds. (2014), When the Party's Over: The Politics of Fiscal Squeeze in Perspective, Proceedings of the British Academy, Vol. 197, Oxford: Oxford University Press. https://doi.org/10.5871/bacad/9780197265734.001.0001

Houlberg, K. (1999), ”Budgetoverskridelsernes anatomi”, Nordisk Administrativt Tidsskrift, Vol. 80 No. 3, pp. 200-232.

Houlberg, K. (2017), ”Lokale styringsvilkårs betydning for kommunernes økonomiske styring fungerer sanktionslovgivningen som brandtæppe eller ilttelt?”, Politica, Vol. 50 No. 1, pp. 45-64.

Jacobs, K. \& Cuganesan S. (2014), "Interdisciplinary accounting research in the Public Sector:

Dissolving boundaries to tackle wicked problems", Accounting, Auditing and Accountability Journal, Vol. 27 No. 8, pp.1250-1256 . https://doi.org/10.1108/aaaj-06-2014-1732

Janke, R., Mahlendorf, M. D. \& Weber, J. (2014), “An exploratory study of the reciprocal relationship between interactive use of management control systems and perception of negative external crisis effects", Management Accounting Research, Vol. 25, pp. 251-270.

https://doi.org/10.1016/j.mar.2014.01.001

Johansson, T. \& Siverbo, S. (2014), “The appropriateness of tight budget control in public sector organizations facing budget turbulence”, Management Accounting Research. Vol. 25, pp. 271-283. https://doi.org/10.1016/j.mar.2014.04.001

Kastberg, G. \& Siverbo, S. (2013), "The design and use of management accounting systems in process oriented health care - An exploratory study”, Financial Accountability and Management, Vol. 29 No. 3, pp. 246-270. https://doi.org/10.1111/faam.12014 
KL (2017), Veje til en mere efektiv drift af botilbvud: De gode eksempler indsamlet af KL og Deloitte i regi af Moderniserings- og Effektiviseringsprogrammet, KL, København.

https://doi.org/10.7146/aul.177.137

KL, Børne- og Socialministeriet, Økonomi- og indenrigsministeriet \& Finansministeriet (2017), Styringen af det specialiserede voksenområde: værktøjer og cases.

Kloot, L. (1997), “Organizational learning and management control systems: responding to environmental change”, Management Accounting Research, Vol. 8, pp. 47-73.

https://doi.org/10.1006/mare.1996.0033

Knutsson, H., Mattisson, O., Ramberg, U., \& Tagesson, T. (2008), "Do strategy and management matter in municipal organisations?”, Financial Accountability \& Management, Vol. 24 No. 3, pp. 295-319. https://doi.org/10.1111/j.1468-0408.2008.00454.x

Kober, R., J. Ng \& Paul B. J. (2007), “The interrelationship between management control mechanisms and strategy”, Management Accounting Research, Vol. 18, pp. 425-452.

https://doi.org/10.1016/j.mar.2007.01.002

Kolk, B. van der, ter Bogt, H.J. \& van Veen-Dirks, P.M.G. (2015), “Constraining and facilitating management control in times of austerity: Case studies in four municipal departments", Accounting, Auditing and Accountability Journal, Vol. 28 No. 6, pp.934-965. https://doi.org/10.1108/aaaj-03$\underline{2014-1660}$

Kolk, B. van der (2019), "Management control packages: a literature review and guidelines for public sector research”, Public Money \& Management.

https://doi.org/10.1080/09540962.2019.1592922

Kominis, G. \& Dudau, A. I. (2012), "Time for interactive control systems in the public sector? The case of the Every Child Matters policy change in England”, Management Accounting Research, Vol. 23, pp. 142-155. https://doi.org/10.1016/j.mar.2012.04.002

Krogstrup, H.K. (1997), Brugerinddragelse og organisatorisk læring i den sociale sektor, Århus, Systime.

Krogstrup, H.K. (2011), Kampen om evidens: Resultatmåling, effektevaluering og evidens, København: Hans Reitzels Forlag.

Kruis, A, Speklé, R. F. \& Widener, S. (2015), "The Levers of Control Framework: An explanatory analysis of balance”, Management Accounting Research, Vol. 32, pp. 27-44.

https://doi.org/10.1016/j.mar.2015.12.002

Kjærgaard, M., Panduro, B., Nørgaard, E., Houlberg, K., Jørgen, N., \& Pedersen, M. (2016). Kommunernes økonomistyring 2016: En afdækning af kommunernes økonomiske resultater og økonomistyringspraksis, KORA. 
Llewellyn, S. (1998), "Boundary work: costing and caring in the social services", Accounting, Organizations and Society, Vol. 23 No. 1, pp. 23-47. https://doi.org/10.1016/s0361$\underline{3682(96) 00036-0}$

Madsen, C.F. \& C. Wisén (2019), "Kunsten at ramme budgettet: Et studie af sanktionslovgivningens betydning for budgetmæssig medgørlighed og politiske budgetcyklusser i de danske kommuner", Økonomi \& Politik, No.1, pp. 81-103.

Malmi, T \& Brown, D. A. (2008), "Management control systems as a package - Opportunities, challenges and research directions", Management Accounting Research, Vol. 19 No. 4, pp. 287-300. https://doi.org/10.1016/j.mar.2008.09.003

Marginson, D. \& Ogden, S. (2005), “Coping with ambiguity through the budget: the positive effects of budgetary targets on managers' budgeting behaviours”, Accounting, Organizations and Society, Vol. 30, pp. 435-456. https://doi.org/10.1016/j.aos.2004.05.004

Marginson, D., McAulay, L. Roush, M. \& van Zijl, T. (2014), "Examining a positive psychological role for performance measures", Management Accounting Research, Vol. 25 No. 1, pp. 63-75.

https://doi.org/10.1016/j.mar.2013.10.002

Martyn, P., Sweeney, B. \& Curtis, E. (2016), "Strategy and Control: 25 years of empirical use of Simons' Levers of Control Framework", Journal of Accounting and Organizational Change, Vol. 12 No. 3, pp. 281-324. https://doi.org/10.1108/jaoc-03-2015-0027

Moll, E. (2017), “Administrative organisationsforandringer i kommunerne efter kriser: Koncernorganisering på flere niveauer?”, Politica, Vol. 49 No. 1, pp. 26-46.

Moynihan, D. P., \& Kroll, A. (2016), "Performance management routines that work? An early assessment of the GPRA modernization act", Public Administration Review, Vol 76 No 2, pp. 314323. https://doi.org/10.1111/puar.12434

Mundy, J. (2010), "Creating dynamic tensions through a balanced use of management control systems”, Accounting, Organizations and Society, Vol. 35, No. 5, pp. 499-523.

https://doi.org/10.1016/j.aos.2009.10.005

Naranjo-Gil, D. (2016), "Role of management control systems in crafting realized strategies", Journal of Business Economics and Management, Vol. 17 No.6, pp. 865-881.

https://doi.org/10.3846/16111699.2014.994558

Nyland, K. \& Pettersen I. J. (2004), “The control gap: the role of budgets, accounting information and (non-) decisions in hospital setting", Financial Accountability and Management. Vol. 20 No. 1, pp. 77-102. https://doi.org/10.1111/j.1468-0408.2004.00187.x

Nørgaard, E., M.S. Kollin, B. Panduro, H. Skov \& M.B. Hansen (2017), Inspiration til økonomisk og faglig styring på det specialiserede børn og unge-område. KORA, København. 
Nørrelykke, H., Zeeberg, B. \& Ebsen F. (2011), Myndighed og leverandør: samspil og aftaler i socialt arbejde med udsatte børn og unge, Institut for Socialt Arbejde, Professionshøjskole Metropol. https://doi.org/10.7146/aul.42.29

Otley, D. (1999), "Performance management: a framework for management control systems research”, Management Accounting Research, Vol. 10, pp. 363-382.

https://doi.org/10.1006/mare.1999.0115

Pedersen, D. (2008), "Strukturreformens styringspolitik - en overskridende dynamic". I Genopfindelsen af den offentlige sektor. Ledelsesudfordringer i reformernes tegn. D. Pedersen, C. Greve \& H. Højlund (eds), København: Børsens Forlag.

Pettersen, I. J. \& Solstad, A. (2015), "Vertical and horizontal control dilemmas in public hospitals", Journal of Health Organization and Management, Vol. 29 No. 2, pp. 185-199.

https://doi.org/10.1108/jhom-01-2013-0003

Pollitt, C. (2006), "Performance management in practice: A comparative study of executive agencies”, Journal of Public Administration Research and Theory, Vol. 16 No. 1, pp. 25-44.

https://doi.org/10.1093/jopart/muio45

Pollitt, C., \& Bouckaert, G. Eds. (2017). Public management reform: A comparative analysis into the age of austerity. New York: Oxford University Press.

Produktivitetskommissionen (2014), Det handler om velstand og velfærd, slutrapport, marts 2014. Rittel, H. W. J. \& Webber, M. M. (1973) “Dilemmas in a General Theory of Planning”, Policy Sciences, Vol. 4, pp. 155-169.

Silverman, D. (2014), Interpreting Qualitative Data. London. Sage.

Simons, R. (1990), "The role of management control systems in creating competitive advantage and new perspectives”, Accounting, Organizations and Society, Vol. 15 No.1/2, pp. 127-143.

https://doi.org/10.1016/0361-3682(90)90018-p

Simons, R. (1991), "Strategic orientation and top management attention to control systems", Strategic Management Journal, Vol. 15, pp. 169-189.

Simons, R. (1995), Levers of Control. How Managers Use Innovative Control Systems to Drive Strategic Renewal. Boston: Harvard Business School Press.

https://doi.org/10.5465/ame.1995.9506273288

Simons, R. (2000), Performance measurement and control systems for implementing strategy, Upper Saddle River: Prentice Hall.

Schrøder, I.-M. (2019), ”Når budgettet skrider: En sporing af økonomiske hensyn i myndighedssagsbehandlerens beslutningsprocesser", Uden for Nummer, Vol. 38, pp. 4-15. 
Speklé, R. F., van Elten, H. J. \& Widener, S. (2017), “Creativity and Control: A Paradox Evidence from the Levers of Control Framework", Behavioral Research in Accounting, Vol. 29 No. 2, pp. 73-96. https://doi.org/10.2308/bria-51759

Speklé, R. F. \& Verbeeten, F. H. M. (2014), "The use of performance measurement systems in the public sector: Effects on performance”, Management Accounting Research, Vol. 25, pp. 131-146. https://doi.org/10.1016/j.mar.2013.07.004

Suenson, E.L, P. Nedergaard \& P.M. Christiansen (2016), "Why lash yourself to the mast? The case of the Danish 'budget law”, Public Budgeting Eं Finance, Vol. 36 No. 1, pp. 3-21.

https://doi.org/10.1111/pbaf.12077

Svanholt, A. K. (2013). Økonomistyring på handicapområdet. I Handicapforståelser: Mellem teori, erfaring og virkelighed, I.S. Bonfils, B. Kirkebæk, L. Olsen \& S. Tetler (eds.). København: Akademisk Forlag.

Sørensen, E. \& Foged, S.K. (2015), ”Mål- og resultatstyring i kommunerne efter krisen”, Økonomi \& Politik, Vol. 88 No. 1, pp. 46-56.

Tessier, S. \& D. Otley (2012), “A conceptual development of Simon’s Levers of Control framework”, Management Accounting Research, Vol. 23, pp. 171-185.

https://doi.org/10.1016/j.mar.2012.04.003

Tuomela, T. S. (2005), "The interplay of different levers of control: A Case-study of introducing a new performance measurement system”, Management Accounting Research, Vol. 16 No. 3, pp. 293320. https://doi.org/10.1016/j.mar.2005.06.003

Van Bueren, E. M., E. Klijn \& J. F. M. Koppenjan (2003), "Dealing with Wicked Problems in Networks: Analyzing an Environmental Debate from a Network Perspective", Journal of Public Administration Research and Theory, Vol. 13, No. 2, pp. 193-212.

https://doi.org/10.1093/jpart/mug017

Van der Stede, W.A. (2001), "Measuring 'tight budgetary control”, Management Accounting Research, Vol. 12, pp. 119-137. https://doi.org/10.1006/mare.2000.0149

Van der Stede, W. A. (2015), "Management accounting: Where from, where now, where to?", Journal of Management Accounting Research, Vol. 27 No. 1, pp. 171-176.

https://doi.org/10.2308/jmar-51059

van Thiel, S., \& Leeuw, F. L. (2002), "The performance paradox in the public sector", Public Performance \& Management Review, Vol. 25 No. 3, pp. 267-281. https://doi.org/10.2307/3381236

Widener, S. K. (2007), "An empirical analysis of the levers of control framework”, Accounting, Organizations and Society", Vol. 32 No. 7-8, pp. 757-788.

https://doi.org/10.1016/j.aos.2007.01.001 
Østergren, K. (2009), "Management control practices and clinical managers: the case of the Norwegian health sector”, Financial Accountability and Management, Vol. 23 No. 2, pp. 133-154.

https://doi.org/10.1111/j.1468-0408.2009.00473.x

\footnotetext{
${ }^{1}$ Det empiriske grundlag for artiklen, er indsamlet af Anne Kirstine Svanholt i et forskningsprojekt, der var finansielt støttet af Innovationsfonden, KMD, COK og Økonomidirektørforeningen. Vi vil gerne takke deltagerne fra kommunen for deres medvirken. Desuden tak til Preben Melander samt en anonym reviewer for gode kommentarer til en tidligere version af artiklen.

${ }^{2}$ Alle sammenligningstal er i dette afsnit korrigeret for ændringer i pris- og lønforudsætninger samt opgaveændringer i medfør af DUT mv. Beløbene er opgjort i 2017-priser.
} 